\title{
Root functioning, tree water use and hydraulic redistribution in Quercus suber trees: A modeling approach based on root sap flow
}

\author{
Teresa S. David ${ }^{\mathrm{a}, \mathrm{g}, *}$, Clara A. Pinto $^{\mathrm{a}}$, Nadezhda Nadezhdina ${ }^{\mathrm{b}}$, Cathy Kurz-Besson ${ }^{\mathrm{c}}$, \\ Manuel O. Henriques ${ }^{\mathrm{d}, \mathrm{g}}$, Teresa Quilhó ${ }^{\mathrm{e}, \mathrm{g}}$, Jan Cermak ${ }^{\mathrm{b}}$, M. Manuela Chaves ${ }^{\mathrm{d}, \mathrm{f}}$, João S. Pereira ${ }^{\mathrm{d}, \mathrm{g}}$, \\ Jorge S. David ${ }^{\mathrm{d}, \mathrm{g}}$ \\ a Instituto Nacional de Investigação Agrária e Veterinária I.P., Quinta do Marquês, Av. da República, 2780-159 Oeiras, Portugal \\ b Institute of Forest Botany, Dendrology and Geobiocenology, Mendel University, Zemedelska 3, 61300 Brno, Czech Republic \\ ${ }^{\mathrm{c} I n s t i t u t o}$ Dom Luiz, Centro de Geofísica da Universidade de Lisboa, Faculdade de Ciências, Campo Grande, Ed. C8, Piso 3, Sala 26, $1749-016$ Lisboa, Portugal \\ ${ }^{\mathrm{d}}$ Instituto Superior de Agronomia, Universidade Técnica de Lisboa, Tapada da Ajuda, 1349-017 Lisboa, Portugal \\ e Centro das Florestas e Produtos Florestais, Instituto de Investigação Científica Tropical, Tapada da Ajuda, 1349-017 Lisboa, Portugal \\ ${ }^{\mathrm{f}}$ Instituto de Tecnologia Química e Biológica, Universidade Nova de Lisboa, Av. da República - EAN, 2780-157 Oeiras, Portugal \\ ${ }^{\mathrm{g}}$ Centro de Estudos Florestais, Universidade Técnica de Lisboa, Tapada da Ajuda, 1349-017 Lisboa, Portugal
}

\section{A R T I C L E I N F O}

\section{Article history:}

Received 14 March 2013

Received in revised form 3 July 2013

Accepted 8 July 2013

Available online 3 August 2013

\section{Keywords:}

Drought

Groundwater

Soil water

Stable isotopes

Xylem anatomy

\begin{abstract}
A B S T R A C T
Mediterranean evergreen oaks have to survive a long summer drought. Roots may play a relevant role under these conditions. We studied their structure and function in a mature Quercus suber L. tree in central Portugal. The root system was mapped till the lowest water table level ( $4.5 \mathrm{~m}$ depth). Xylem anatomy was analyzed in a vertical profile belowground. Sap flow was continuously monitored for 1.5 yrs in the stem and roots of this intensively studied tree (heat field deformation method) and in the stem of four trees (Granier method), in relation to environmental variables and predawn leaf water potential. The sources of water uptake were assessed by stable isotope analyses in summer. Results showed a dimorphic root system with a network of superficial roots linked to sinker roots, and a taproot diverting into tangles of deep fine roots submerged for long periods, with parenchyma aerenchyma. Transpiration was not restricted in summer due to root access to groundwater. The isotopic $\delta^{18} \mathrm{O}$ signature of twig xylem water was similar to that of groundwater in the dry season. Two functional types of superficial roots were identified: shallow connected and deep connected roots. A modeling approach was built considering that each superficial root was linked to a sinker, with part of the root deep connected (between the stem and the sinker) and part shallow connected (between the sinker and topsoil). This conceptual framework simulated tree stem sap flow from root sap flow with a high efficiency $\left(R^{2}=0.85\right)$ in four plot trees.

On an annual basis, soil water and groundwater contributions were $69.5 \%$ and $30.5 \%$ of stem flow, respectively. Annual hydraulic lift and hydraulic descent were $0.9 \%$ and $37.0 \%$ of stem flow, respectively. The trees maximize the exploitation of the environmental resources by using the topsoil water during most of the year, and groundwater together with hydraulic lift (nutrient supply) in the dry summer. This study shows that a dimorphic root system, with roots reaching groundwater, is an efficient strategy of $Q$. suber trees to cope with seasonal drought. Knowledge of the functional behavior of $Q$. suber trees under shallow water table conditions may contribute to the definition of better adapted management practices and to anticipate their responses to climate change.
\end{abstract}

(c) 2013 Elsevier B.V. All rights reserved.

\footnotetext{
* Corresponding author at: Instituto Nacional de Investigação Agrária e Veterinária I.P., Quinta do Marquês, Av. da República, 2780-159 Oeiras, Portugal. Tel.: +351 214463760; fax: +351 214463701 .

E-mail addresses: teresa.david@iniav.pt (T.S. David), clara.pinto@iniav.pt (C.A. Pinto), nadezdan@mendelu.cz (N. Nadezhdina), cbbesson@fc.ul.pt (C. KurzBesson), mhenriques@isa.utl.pt (M.O. Henriques), terisantos@isa.utl.pt (T. Quilhó), cermak@mendelu.cz (J. Cermak), mchaves@itqb.unl.pt (M.M. Chaves), jspereira@ isa.utl.pt (J.S. Pereira), soaresdavid@isa.utl.pt (J.S. David).
}

\section{Introduction}

Mediterranean climate has a strong seasonality and variability. Vegetation has to withstand hot and dry summers as well as recurrent droughts, which may become more frequent in the future according to climate change projections (IPCC, 2007). Lack of natural regeneration and episodes of tree mortality have been ascribed to droughts (Allen et al., 2010; Peñuelas 
et al., 2001; van Mantgem et al., 2009). Mediterranean evergreen oaks, usually in agroforestry systems, have evolved a wide range of morphological, physiological and anatomical adaptations to survive the prolonged dry summer season. Extensive root systems may play a key role in this process (Baldocchi and $\mathrm{Xu}$, 2007; David et al., 2004, 2007; Lubczynski and Gurwin, 2005; Nadezhdina et al., 2008).

In water-limited environments, roots may extend far beyond the crown projection area (David et al., 2004; Moreno et al., 2005), grafting either within the same tree or between adjacent trees. Deep rooting is also an important feature for tree survival (Canadell et al., 1996; Schenk and Jackson, 2002), enabling the exploitation of deep soil or groundwater pools (Cermak et al., 1980; Dawson, 1996; Jackson et al., 1999), when water tables are within the reach of the roots. By accessing deep water sources, deep roots may also contribute to the increase in whole-plant water transport efficiency through hydraulic redistribution. Responding to water potential gradients in soil, water may move upwards (hydraulic lift), downwards (hydraulic descent or reverse hydraulic lift) or laterally (Nadezhdina et al., 2010; Prieto et al., 2012).

The spatial configuration of the xylem system also affects tree hydraulic properties and environmental adaptation. Vessel size and frequency determine the water transport efficiency (hydraulic conductivity) and safety (vulnerability to cavitation) (MartínezVilalta et al., 2002; Pinto et al., 2012).

Although increasing attention has been given to the role of tree roots on the adaptation to water-limited environments, this issue is far from being unraveled. A previous study on sap flow (heat field deformation method) in superficial roots of a Quercus suber tree provided a first insight into some traits of root functioning (Nadezhdina et al., 2008). Two types of behavior were found in five superficial roots: in some sap flow increased (deep roots connected to groundwater) whereas in others it decreased (shallow roots connected to soil) during the dry summer. According to Nadezhdina et al. $(2008,2010)$ these different types of behavior seem to depend on sensor location relative to sinkers connected to the superficial roots. However, the exact role, representativeness and quantitative assessment of the contribution of these root types to whole tree water use and hydraulic redistribution are still unclear (Nadezhdina et al., 2008, 2010), although critical for a better perception of the functional traits of Mediterranean evergreen oaks. In this work we aimed to overcome this gap in knowledge through the evaluation of root structure and function on the water relations of a mature cork oak (Quercus suber) tree under shallow water table conditions, in central/southern Portugal. The specific objectives were: (a) mapping the root system, both laterally and in depth, and characterize the anatomical features of the different root types; (b) characterize the typical patterns of water flow in roots connected to deep and surface water sources; (c) evaluate, through the modeling of root functioning, the magnitudes of water uptake from soil and groundwater, and hydraulic redistribution at the tree level. We hypothesized that whole tree water use and hydraulic redistribution might be mechanistically modeled from the dynamics of deep and shallow root water uptake. This modeling attempt should not be viewed with predictive purposes (since root sap flow is seldom available) but rather as a framework, based on the experimental data, for trying to understand how the root system works.

We used the supersonic air-stream (air-spade) and vertical digging down to the water table to map the root system. Sap flow was measured in stems (heat field deformation, HFD, and Granier methods) and in roots (HFD method) in tandem with soil moisture, groundwater, and stable isotope ${ }^{18} \mathrm{O}$ to study the water uptake from the different pools related to root functioning.

\section{Materials and methods}

\subsection{Experimental site and plant material}

Measurements were done between March 2007 and December 2008 at Companhia das Lezirias, the largest Quercus suber L. woodland close to Lisbon, Portugal ( $38^{\circ} 50^{\prime} \mathrm{N} ; 8^{\circ} 49^{\prime} \mathrm{W} ; 15 \mathrm{~m}$ above sea level). It is a savannah-type ecosystem with widely separated trees (ca. 30 trees ha ${ }^{-1}$ ). The climate is Mediterranean, with hot and dry summers and wet and cold winters. Rainfall occurs predominantly from October to April. Long-term (1951-1980) mean annual rainfall is $708 \mathrm{~mm}$, mean annual temperature is $15.6^{\circ} \mathrm{C}$ (ranging from $9.9^{\circ} \mathrm{C}$ in January to $22.0^{\circ} \mathrm{C}$ in August) and open water evaporation is $1347 \mathrm{~mm}$ (Pegoes Meteorological Station). The soil is a welldrained deep Haplic Arenosol, with high permeability and a low water retention capacity, overlying a thick clay layer at ca. $9 \mathrm{~m}$ depth. At this site the water relations of four cork oak trees were analyzed. Tree height, diameter at breast height, and crown projected area varied between 12.1 and $14.5 \mathrm{~m}, 0.57$ and $0.98 \mathrm{~m}$, and 172.3 and $247.9 \mathrm{~m}^{2}$, respectively. One of these trees was intensively monitored to study root structure and functioning. Tree age was estimated to be 60 years by counting annual growth rings in a cross-section near the base of the trunk. Tree mean height, diameter at breast height, and crown projected area were $12.1 \mathrm{~m}, 0.57 \mathrm{~m}$, and $172.3 \mathrm{~m}^{2}$, respectively. The distance to the nearest neighbor was $18 \mathrm{~m}$. Tree leaf area index, on a crown projected area basis, was estimated by destructive sampling at the end of the experiment: $5.1 \mathrm{~m}^{2} \mathrm{~m}^{-2}$ (David et al., 2012). Root structure could only be analyzed in this tree since $Q$. suber is a protected species and destructive sampling is restricted. However, the representativeness of its water status was checked by comparing its predawn leaf water potential with those of ten neighboring trees (see Section 3.2) and its stem sap flow with those of three neighboring ones. Moreover, the lithology and hydrogeology is spatially homogeneous at the site.

\subsection{Root system mapping}

By the end of the experimental period (September 2008) the superficial root system was uncovered using a supersonic thin air stream (Air-Spade Technology, Verona, PA, USA). The air spade was connected to an Ingersoll-Rand compressor providing an air flow rate of $12 \mathrm{~m}^{3} \mathrm{~min}^{-1}$ at an operating pressure of $1.2 \mathrm{MPa}$. It converts the energy of compressed air into digging power (which removes soil from roots). The superficial root system was uncovered to $1 \mathrm{~m}$ depth, from the tree trunk to beyond the crown limits. Digging proceeded with a backhoe, on the south side of the crown, from tree trunk down to the water table level (ca. $4.5 \mathrm{~m}$ depth).

\subsection{Xylem anatomy}

We measured vessel diameter distribution, the fraction of crosssectional area occupied by vessels, and vessel density in stem and roots. Stem discs were collected at breast height. Root discs were collected in a vertical profile from stem base to the water table level, and in lateral and sinker roots. From each disc 2-3 radial strips free of defects were randomly selected. To sample the conductive area, two $1.5 \mathrm{~cm} \times 1.5 \mathrm{~cm}$ wood sections (where applicable) were cut from each radial strip at approximately $10 \%$ ray distance from the cambium. Samples were fixed permanently with formalin-acetic acid-alcohol (FAA). Transverse sections (ca. $20 \mu \mathrm{m}$ thick) were obtained using a sledge microtome (Leica SM2400, Leica Microsystems GmbH, Nussloch, Germany), stained with safranine (1\%) for 1-3 min, and mounted with Entellan. Cross sections were viewed in a light microscope system (Leica CTR Mic) interfaced with a dig- 
ital camera (Leica DMAL, Leica Microsystems, Heerbrugg, Switzerland) at $5 \times 10 \times 2$. The inner diameters of all open vessels $(\mu \mathrm{m})$ were measured using the image analysis software Leica QWin Plus V. 3.5.0 (Leica Microsystems, Heerbrugg, Switzerland). Mean vessel diameter $(\mu \mathrm{m})$ and total vessel area per unit of sampled area $\left(\mu \mathrm{m}^{2} \mu \mathrm{m}^{-2}\right)$ were calculated for each cross-section.

\subsection{Meteorological data}

An automatic weather station was installed at the plot on top of a $16 \mathrm{~m}$ high instrument tower. Solar radiation (CM6B, Kipp and Zonen, Delft, The Netherlands), dry and wet bulb temperatures (aspirated psychrometer H301, Vector Instruments, Rhyl, UK) and gross rainfall (tipping-bucket rain gauge recorder ARG100, Environmental Measurements, Gateshead, UK) were recorded at 10-min intervals by CR10X data loggers (Campbell Scientific, Shepshed, UK). Values were averaged or totaled hourly and daily. Air vapor pressure deficit was calculated from dry and wet bulb temperatures.

\subsection{Groundwater table}

Fluctuations in groundwater level were monitored in a borehole by a pressure transducer (PDCR 830, Campbell Scientific) which measures the difference in pressure between the atmosphere and at the depth of the sensor. Data were recorded at 30-min intervals by a CR10X data logger (Campbell Scientific, Shepshed, UK).

\subsection{Soil water content}

Soil volumetric water content at $0.25,0.50$ and $0.75 \mathrm{~m}$ depth was measured at 30-min intervals by ECH2O $20-\mathrm{cm}$ probes (Decagon Devices, Pullman, WA) connected to a CR 23X data logger (Campbell Scientific, Shepshed, UK). Values reported represent means of nine sensors, three per depth. Probe readings were calibrated against gravimetric samples taken, periodically, adjacent to the probes.

\subsection{Xylem, soil and groundwater stable oxygen isotopic composition}

Q. suber water uptake sources were analyzed by comparing the ${ }^{18} \mathrm{O} /{ }^{16} \mathrm{O}$ isotope ratio $\left(\delta^{18} \mathrm{O}\right)$ of twig xylem water (in a sample of four trees including the intensively studied one) with that of soil water and groundwater. Since plant roots do not discriminate between the two oxygen isotopes, the isotopic composition of the xylem sap should reflect the relative proportion of root water uptake from the different sources.

Twig, soil and groundwater samples were collected in two days per summer period (26 June and 14 August 2007; 13 August and 10 September 2008). Two lignified $10 \mathrm{~cm}$-twigs per tree (four trees) were sampled at midday at a minimum of $10 \mathrm{~cm}$ from the leaves. All leaves and green stem tissue were removed from twigs to avoid contamination of the remaining xylem water by isotopically enriched water (Dawson and Ehleringer, 1993). Three soil water samples were collected at each sampling depth $(0.3,0.5$ and $0.7 \mathrm{~m}$ depth). Groundwater samples, collected from the borehole installed at the plot, were hermetically sealed with parafilm to avoid any alteration of the isotopic signature due to evaporation. Samples were stored at $-18{ }^{\circ} \mathrm{C}$ until water extraction (by cryodistillation in soil and twig samples) and analysis by mass spectrometry (Kurz-Besson et al., 2006).

Isotopic $\delta^{18} \mathrm{O}$ signatures were expressed in relation to the VSMOW international standard in parts per thousand as:

$\delta^{18} \mathrm{O}=\left(R_{\text {sample }}-R_{\text {standard }}\right) /\left(R_{\text {standard }}\right) 1000$ where $R$ is the isotope ratio of ${ }^{18} \mathrm{O} /{ }^{16} \mathrm{O}$.

\subsection{Predawn leaf water potential}

Predawn leaf water potential $\left(\Psi_{1, \mathrm{pd}}, \mathrm{MPa}\right)$ was measured monthly or at shorter intervals (summer) using a Scholander pressure chamber (PMS 1000, PMS Instruments, Corvalis, Oregon, USA) (Scholander et al., 1965). At each sampling time, three to four leaves were collected at similar heights from the South-facing part of the crowns and immediately measured. In order to assess the representativeness of the water status of the intensively studied tree, $\Psi_{1, p d}$ was also monitored at each measuring day in ten neighboring trees.

\subsection{Sap flow in stem and roots}

Sap flow was monitored by the heat field deformation (HFD) technique (Nadezhdina et al., 2008) in stem and roots of the intensively studied tree. We used multi-point sensors in stem (SE, SW, NE and NW azimuths) and single-point sensors in five small superficial roots (Table 1). Each sap flow sensor consisted of a heater and two pairs of differential thermocouples installed radially in the sapwood. Both the heater and the thermocouples of each sensor were mounted into stainless steel hypodermic needles $(1.0$ and $1.5 \mathrm{~mm}$ in diameter for single- and multi-point sensors, respectively). Each stem multi-point sensor contained five or six equally spaced thermocouples, 8-10 mm apart. Stem sensors were shielded from potential sunflecks by reflective insulation. Root single-point sensors were installed after soil opening and surface cleaning, were shielded by silicone rubber and protected with plastic boxes before soil re-covering.

The HFD method records changes in the heat field around a continuous linear heater caused by the moving sap. Sap flow is derived from the temperature difference in axial and tangential directions recorded, respectively, by the symmetrical and asymmetrical pairs of thermocouples. Further details on the HFD method are given elsewhere (Nadezhdina et al., 2008). The temperature data were recorded by Campbell CR10X loggers (Campbell Scientific, Shepshed, UK). From these data, sap flow per a certain stem or root section $\left(\mathrm{g} \mathrm{cm}^{-1} \mathrm{~h}^{-1}\right)$ was calculated and converted into sap flow density $\left(\mathrm{g} \mathrm{cm}^{-2} \mathrm{~h}^{-1}\right)$, by dividing by the xylem radius of the corresponding sapwood section. Sap flow was obtained by integrating sap flow density over the entire sapwood depth. The depth of the sapwood in tree stem was $57 \mathrm{~mm}$ (David et al., 2012). Whole-tree stem sap flow was obtained by averaging flows from the four sampled azimuths. Root sapwood depth was estimated based on anatomical observations, subtracting the heartwood depth when present. It was found to be equal to the xylem radius in the smaller roots or slightly smaller in the large ones.

The seasonal courses of sap flow in roots and stem were analyzed to characterize the patterns of water uptake and hydraulic redistribution, and to infer root behavior and functioning

Table 1

Positioning of the sap flow sensors in small roots, around the Quercus suber tree stem.

\begin{tabular}{llll}
\hline $\begin{array}{l}\text { Root } \\
\text { identification }\end{array}$ & Azimuth & $\begin{array}{l}\text { Distance from stem } \\
\text { base }(\mathrm{m})\end{array}$ & $\begin{array}{l}\text { Root xylem } \\
\text { diameter }(\mathrm{m})\end{array}$ \\
\hline Root 1 & $(\mathrm{SE})$ & 1.60 & 0.033 \\
Root 2 & $(\mathrm{SE})$ & 1.77 & 0.016 \\
Root 3 & $(\mathrm{SW})$ & 1.72 & 0.021 \\
Root 4 & $(\mathrm{~W})$ & 2.92 & 0.041 \\
Root 5 & $(\mathrm{NW})$ & 1.67 & 0.050 \\
\hline
\end{tabular}


(connections to deep soil/groundwater or surface soil water sources). Stem sap flow was modeled taking into account the contribution of the different types of sampled roots.

The HFD method is highly sensitive to low, zero and bi-directional flows. Positive sap flows in roots indicate that water is moving in acropetal direction, i.e. from roots to stem. Negative (reverse) flows in roots mean that water is moving opposite to the normal (acropetal) direction.

Stem sap flow density in the outer $20 \mathrm{~mm}$ of xylem was also measured in four $Q$. suber trees (including the intensively studied one) by the Granier method (Granier, 1985), from spring 2007 (April) to summer 2008 (September). Two sap flow sensors (UP $\mathrm{GmbH}$, Landshut, Germany) were radially installed in the northand south-facing stem xylem of each tree. Half hourly data were stored in CR23X data loggers (Campbell Scientific, Shepshed, UK). Tree sap flow was calculated from sap flow density and the radial sap flow profiles measured by multipoint HFD sensors.

\subsection{Statistical analyses}

Differences in mean vessel diameter between tree organs/sections were tested through Analysis of Variance. Post-hoc analyses were conducted using the Tukey-Kramer test for the multiple comparisons of means. All tests were done using the statistics software package IBM SPSS Statistics19.0.0 (IBM Corporation, Somers, NY, USA), at a minimum significance level of $5 \%(\alpha=0.05)$. The mean isotopic signatures of xylem water, groundwater and soil water (from 0.3 to $0.7 \mathrm{~m}$ depth) were compared using the same procedure.

\section{Results}

\subsection{Environmental data}

During the experimental period, the evaporative demand was highest in summer, reflecting both the patterns of solar radiation and vapor pressure deficit (Fig. 1a and b). Rainfall was mainly concentrated in autumn-winter and scarce or absent in summer (particularly in 2008) (Fig. 1b). Topsoil moisture content $\left(\mathrm{m}^{3} \mathrm{~m}^{-3}\right)$ mostly reflected the rainfall pattern reaching a minimum at the end of summer. Groundwater table recharged during winter and spring, lagging behind rainfall, and progressively declined during the summer drought, extending into the autumn. It peaked in March 2007 and May 2008 (1.3 m and $3.2 \mathrm{~m}$ depth, respectively) and was lowest by December of both years ( $4.2 \mathrm{~m}$ and $4.5 \mathrm{~m}$ depth in 2007 in 2008, respectively).

\subsection{Predawn leaf water potential}

Predawn leaf water potential, a surrogate of mean water potential at the roots surface, remained high throughout the experimental period (above $-0.5 \mathrm{MPa}$ ). A similar pattern was observed in the ten neighboring trees (slope $=1.06$ and $R^{2}=0.92$, in a linear regression through the origin between the intensively studied tree and the average of the ten surrounding individuals).

\subsection{Root mapping}

The belowground mapping of the intensively studied Quercus suber tree evidenced a dimorphic root system (Fig. 2). We observed a dense network of superficial lateral roots growing at $10-40 \mathrm{~cm}$ depth (uncovered by the air spade), connected to sinker roots, and a taproot (uncovered by mechanical and manual digging) penetrating into deep soil. The proliferation of superficial tree roots decreased considerably below $60 \mathrm{~cm}$ depth.
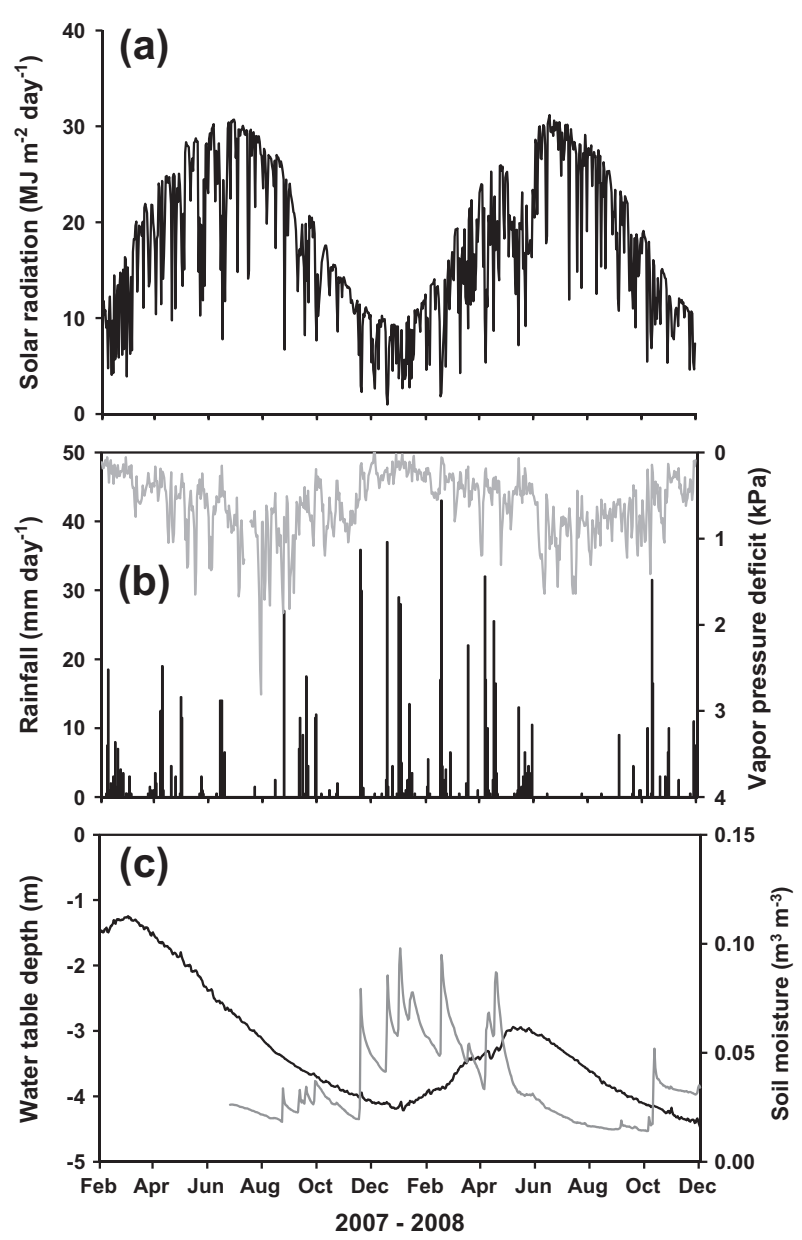

Fig. 1. Seasonal courses of daily solar radiation (a), daily rainfall and daily mean air vapor pressure deficit (b), groundwater table depth and topsoil (0.25-0.75 m depth) volumetric water content (average of three sensors per depth) (c).

Lateral roots extended beyond the crown projection limits, though restricted by prior soil tillage. From the horizontal lateral roots emerged vertical sinkers till the crown limits (within the drip line).

The large taproot, circular at stem basis, branched into smaller ramifications from about $1.5 \mathrm{~m}$ depth downwards. Below $3 \mathrm{~m}$ depth, tangles of fine root filaments were observed. These deep fine root filaments are submerged for long periods of the year, depending on water table fluctuations, and have parenchyma aerenchyma in their cortex (see Fig. 2).

\subsection{Xylem anatomic traits}

The vertical profile of root conduit size (mean vessel diameter, $\mu \mathrm{m}$ ) showed a top-down decreasing trend (Fig. 3b). Differences in mean vessel diameter between root types/sections were always statistically significant $(P<0.05)$, except between taproot section at $1 \mathrm{~m}$ depth (taproot 1 ) and sinkers. The decrease in mean vessel diameter below the superficial lateral root at stem base was: $17 \%$ in taproot 1 and sinker roots, 30.2\% in taproot section at $2.6 \mathrm{~m}$ depth (taproot 2 ) and $81.1 \%$ in the deep fine root filaments.

The total vessel area per unit of sampled area $\left(\mu \mathrm{m}^{2} \mu \mathrm{m}^{-2}\right)$ decreased from lateral root at stem base to taproot 1 and $2(23.6 \%$ and $56.0 \%$, respectively) but significantly increased in the sinkers and deep fine root filaments (33.5\% and $102.0 \%$, respectively) (Fig. 3a). 


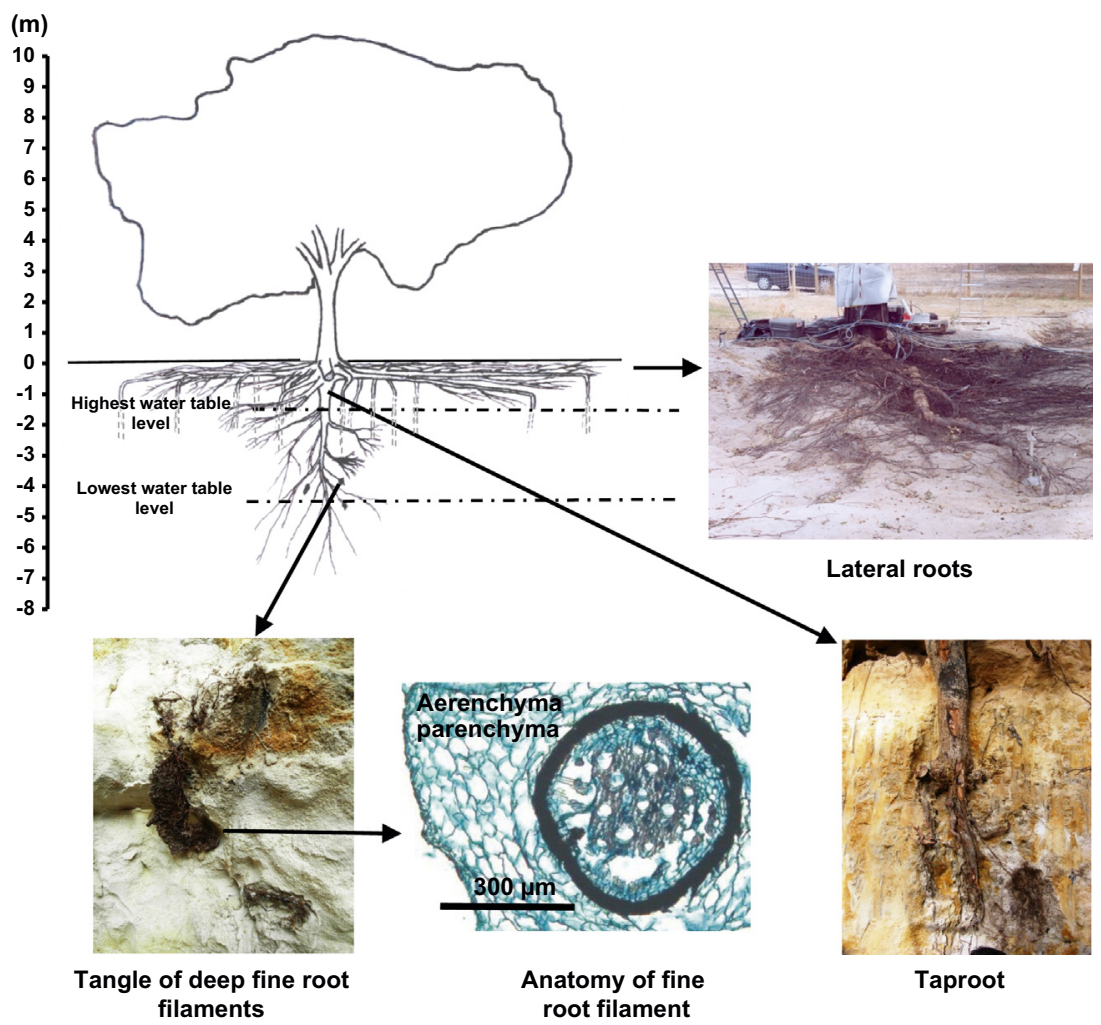

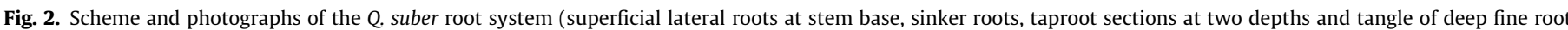

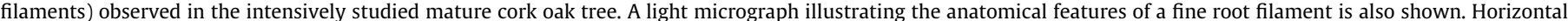
dashed lines are the boundaries of the water table fluctuations.
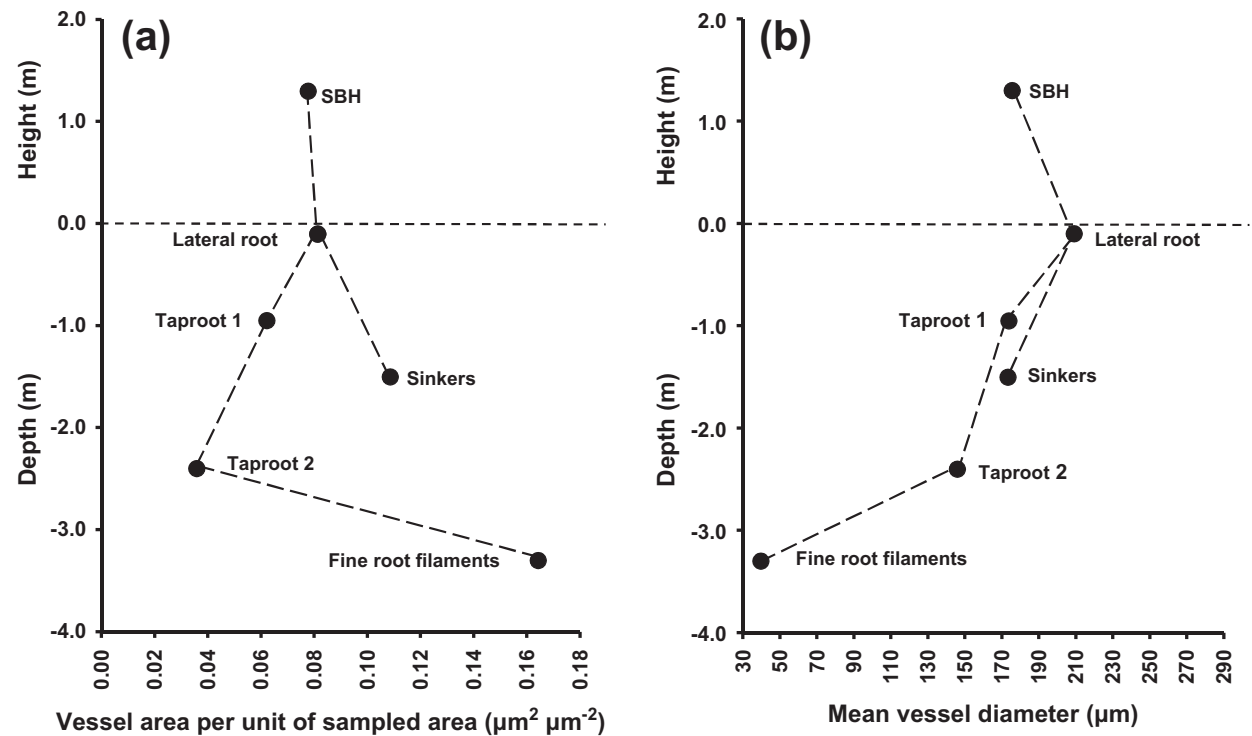

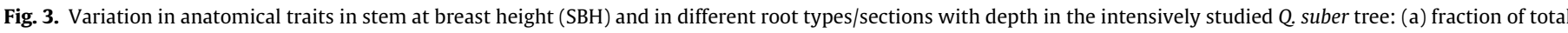
vessel area in sampled area; (b) mean vessel diameter. Error bars (standard error) are contained within the symbol size.

\subsection{Sap flow in roots and stem}

From the seasonal variation of sap flow in stem and superficial roots, in response to environmental drivers, it was possible to infer different root behavior and functioning (Fig. 4).

Stem sap flow (Fig. 4a) closely followed the radiation pattern (Fig. 1a): daily stem flow $\left(\mathrm{kg} \mathrm{day}^{-1}\right)=5.5 \times$ daily solar radiation $\left(\mathrm{MJ} \mathrm{m}{ }^{-2}\right.$ day $\left.^{-1}\right)+4.6 ; R^{2}=0.73$. Therefore, tree transpiration was not limited by water supply during the dry summer. Similarly, in roots 1 and 4 (Fig. 4b and c) (hereafter referred as deep connected roots), daytime sap flow followed the radiation pattern peaking in summer when the topsoil was dry, and declining in winter. Nighttime reverse flows (negative) were observed in the rainy winter, evidencing the occurrence of hydraulic descent (reverse hydraulic lift). This means that these roots are connected to deep water sources, from where they absorb water during summer. In roots 

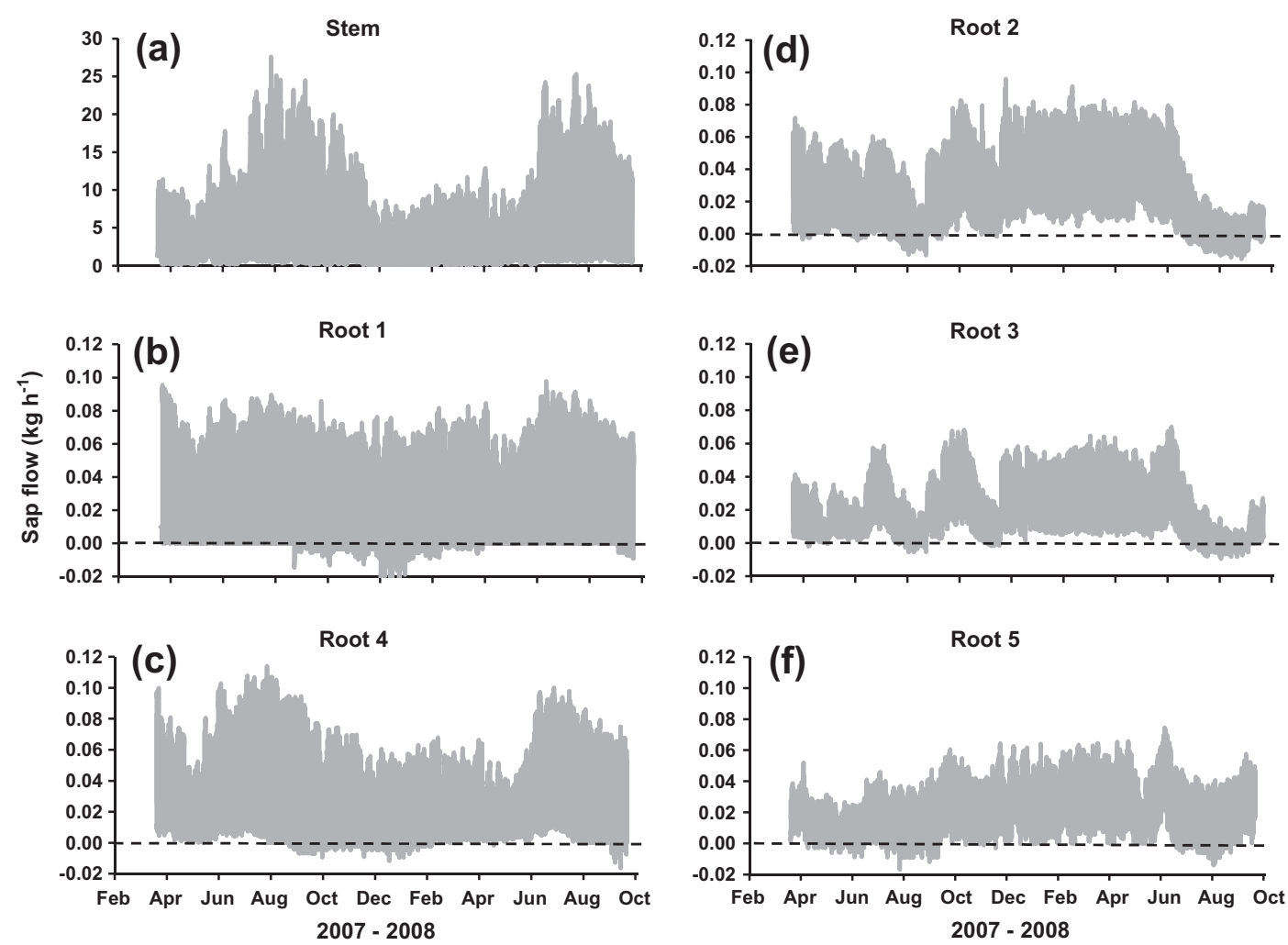

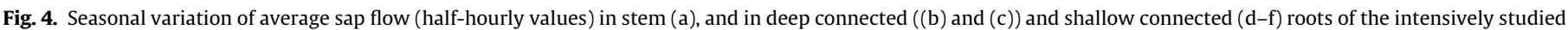
Q. suber tree.

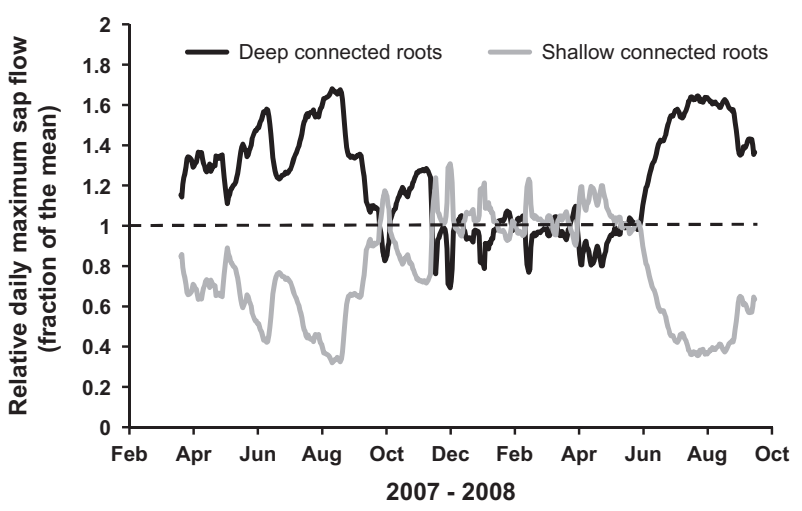

Fig. 5. Seasonal variation of the relative contribution (fraction of the mean) of the deep and shallow connected roots in the overall water uptake of the intensively studied Q. suber tree. Horizontal dashed line indicates an equal (mean) contribution of deep and shallow connected roots.

2, 3 and 5 (Fig. 4d-f) (hereafter referred as shallow connected roots), maximum daytime sap flow decreased in summer and peaked in autumn-winter upon topsoil rewetting, following the seasonal variations in topsoil moisture (Fig. 1c). Reverse (negative) nighttime flows occurred during the dry summer, particularly in 2008 , indicating hydraulic lift. This type of behavior suggests that these roots are connected to topsoil layers.

Fig. 5 illustrates the seasonal dynamics of the relative importance of individual deep and shallow connected roots in the overall water uptake. Lines in the Figure represent the trends of maximum daily sap flow for the two types of roots (deep connected - average of 1 and 4; shallow connected - average of 2, 3 and 5) normalized by the mean of the two root types. The dashed line indicates that sap flow is equal to the mean (values equal to one). Individual deep and shallow connected roots have quite similar flows during winter. However, during summer, when surface soil dries, flow in individual deep connected roots is much higher than in shallow connected roots.

\subsection{Xylem, soil and groundwater stable oxygen isotopic composition}

During summers of 2007 and 2008, $\delta^{18} \mathrm{O}$ signature was similar in xylem water and groundwater and significantly more negative than that of soil water (0.3-0.7 m layer) (Table 2$)$. This indicates that the direct use of groundwater by trees prevailed during the summers.

\subsection{Modeling whole tree water use from sap flow of deep and shallow} connected roots

To simulate stem sap flow from root sap flow $\left(\mathrm{kg} \mathrm{day}^{-1}\right)$ we assumed that the functional behavior of the two types of superficial sampled roots was representative of the whole root system: average of roots 1 and 4 for deep connected roots and average of roots 2, 3 and 5 for shallow connected roots (see Fig. 4). This assumption is reinforced by the results of Nadezhdina et al. (2008) who found the same two behavioral root types in a $Q$. suber at a different site.

Two modeling conceptual frameworks were tested considering that: (a) root types work in parallel (Model 1); (b) root types work in series (Model 2) (Fig. 6). In Model 2, T-type model, each superficial root is considered connected to one sinker. Part of the root, between the sinker and the stem, behaves as deep connected and the other part, between the sinker and superficial soil, behaves as shallow connected. In this Model, the flow in the sinker (not measured) was calculated according to the mass balance equation (in $\mathrm{kg} \mathrm{day}^{-1}$ ): 
Table 2

Stable oxygen isotopic signature $\left(\delta^{18} \mathrm{O}\right)$ of twig xylem water (average of four trees including the intensively studied one) compared to shallow soil (average of the $0.3-0.7 \mathrm{~m}$ depth, 3 samples per depth) and groundwater, during summers of 2007 and 2008 . Values between brackets are standard error of the mean. Within each line mean values followed by the same letter are not significantly different $(P<0.05$; Tukey-Kramer test).

\begin{tabular}{llll}
\hline & \multicolumn{2}{l}{} & \\
\cline { 2 - 4 } & Xylem water & Groundwater & Soil water $(0.3-0.7 \mathrm{~m}$ depth $)$ \\
\hline 26 June 2007 & $-4.06(0.31) \mathrm{a}$ & $-4.50(0.05) \mathrm{a}$ & $0.97(0.33) \mathrm{b}$ \\
14 August 2007 & $-4.78(0.19) \mathrm{a}$ & $-4.03(0.07) \mathrm{a}$ & $-2.49(0.51) \mathrm{b}$ \\
13 August 2008 & $-4.75(0.15) \mathrm{a}$ & $-4.98(0.51) \mathrm{a}$ & $1.96(0.70) \mathrm{b}$ \\
10 September 2008 & $-4.84(0.21) \mathrm{a}$ & $-5.44(0.46) \mathrm{a}$ & $-1.86(0.67) \mathrm{b}$ \\
\hline
\end{tabular}

Model 1

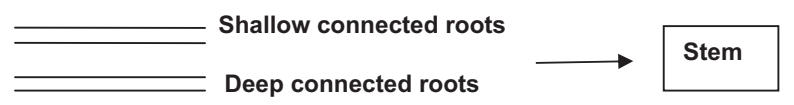

Model 2 (T- type)

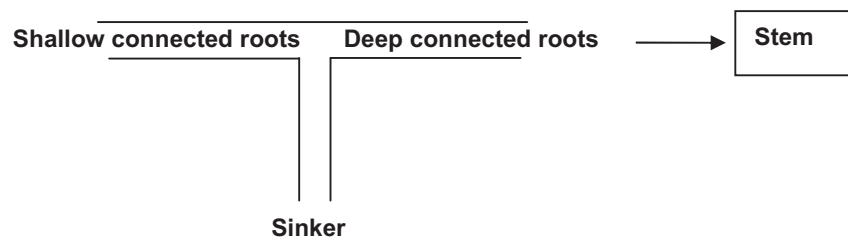

Fig. 6. Conceptual frameworks of the two models tested to simulate stem sap flow from root sap flow.

\section{Flow deep connected $=$ Flow shallow connected + Flow sinker}

which is valid for both positive and negative flows.

In Model 1, stem sap flow was simulated as:

Flow stem $=n 1 \times$ Flow deep connected $+n 2$

$$
\times \text { Flow shallow connected }
$$

where $n 1$ and $n 2$ are the number of equivalent deep and shallow connected conductors, respectively, expected to be different in this case.

In Model 2, stem sap flow was simulated as:

Flow stem $=n 1 \times$ Flow deep connected

where $n 1$ is the number of equivalent deep connected conductors, equal to the number of shallow connected conductors. Stem flow will only depend on the flow of deep connected roots since it integrates both the flow from sinkers and shallow connected roots (see Fig. 6 and Eq. (2)).

In both models $n 1$ and $n 2$ do not represent the number of real roots but the theoretical number of equivalent roots (with flow equal to the average of each individual sampled root type).

Parameter $n 1$ was estimated (for both models) as the slope of the linear regression through the origin between daily stem sap flow and deep connected root sap flow, when shallow root sap flow was negligible (less than $10 \%$ of average: $>-0.11$ and $<0.11 \mathrm{~kg} \mathrm{day}^{-1}$; stem sap flow $=229.91 \times$ deep connected root sap flow, $R^{2}=0.54, n=29$; estimated $n 1=230$ ).

Parameter $n 2$ for Model 1 was estimated as the slope of the linear regression through the origin between daily stem sap flow and shallow connected root sap flow, when deep root sap flow was negligible (less than $10 \%$ of average: $>-0.1$ and $<0.1 \mathrm{~kg}$ day $^{-1}$; stem sap flow $=48.22 \times$ shallow connected root sap flow, $R^{2}=0.50$, $n=11$; estimated $n 2=48$ ).

To test the assumptions of Model 2 we estimated the number of shallow connected conductors ( $n 2$ ) when sinker root sap flow

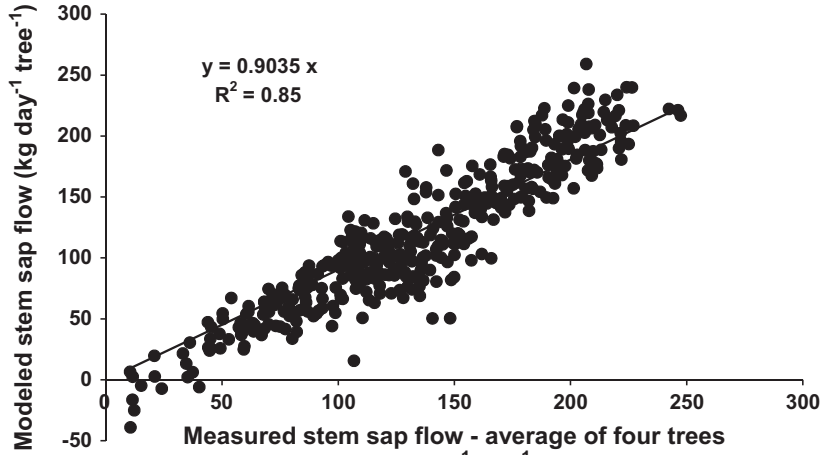

$\left(\mathrm{kg} \mathrm{day}^{-1}\right.$ tree $\left.^{-1}\right)$

Fig. 7. Validation of daily stem flow estimated by Model 2 (T-type) against average daily stem flow of four trees measured by the Granier method.

(calculated) was negligible (less than 10\% of average: $>-0.03$ and $<0.03 \mathrm{~kg} \mathrm{day}^{-1}$; stem sap flow $=202.11 \times$ shallow connected root sap flow, $R^{2}=0.55, n=12$; estimated $n 2=202$ ). The number of shallow connected roots (202) is close to that estimated for the deep connected roots (230). The small difference (14\%) suggests that the conceptual framework of Model 2 is basically correct. In this Model, parameter $n 1$ was considered equal to the average of these two values (216).

The two models were validated against daily stem sap flow (HFD method) measured in the whole studied period in the intensively studied tree. Model 2 performed much better than Model 1 ( modeled values $=1.09 \times$ measured values, $R^{2}=0.71$ for Model 2; and modeled values $=1.31 \times$ measured values, $R^{2}=0.48$ for Model 1). Model 2 was also validated against measured half-hourly stem flow in the same tree and model efficiency was even higher: modeled values $=1.09 \times$ measured values, $R^{2}=0.88$ ). Model 2 was additionally validated against the average daily stem sap flow of the four trees measured by the Granier method, using the parameters and the average sap flow of deep connected roots estimated/ observed in the intensively studied tree. Model performance was again very good $\left(R^{2}=0.85\right.$; Fig. 7$)$.

\subsection{Estimation of water balance and hydraulic redistribution for the whole tree}

Considering that the T-type Model 2 reproduces well the bulk of the behavior of the root system, we used it to simulate root functioning along the different seasons. Fig. 8 illustrates the expected root functioning in the wet and dry seasons (day and night).

During daytime in the dry season, predominant flow comes from groundwater through sinkers which feed the deep connected parts of superficial roots (Fig. 8a, day). The water uptake by sinkers is also responsible for the occurrence of the nighttime hydraulic lift in the shallow connected parts of superficial roots (Fig. 8a, night). 

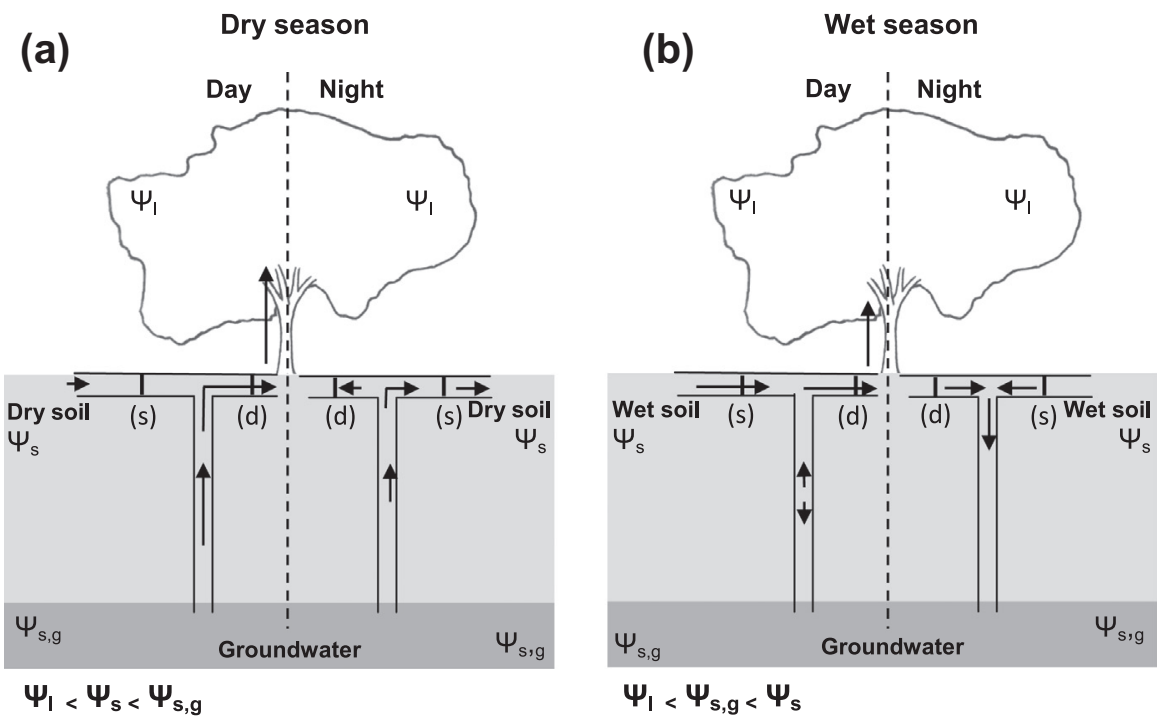

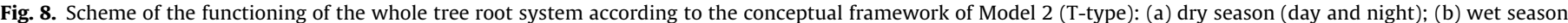
(day and night). (s) and (d) refer to shallow connected or deep connected superficial roots, respectively. Arrows indicate the direction of flow.

During daytime in the wet season, predominant flow comes from the wet soil which feeds the shallow and the deep connected parts of superficial roots (flow about the same in the two root types (Fig. 8b, day)). In this case the contribution of groundwater will be minor. During nighttime flows from the shallow (positive) and deep connected roots (negative) converge into the sinker producing hydraulic descent (Fig. 8b, night).

The aforementioned conceptual interpretation of root functioning is consistent with the patterns of sap flow measured in individual roots (see Figs. 4 and 5), and simulates well stem flow (see Section 3.7, Fig. 7). This suggests that the T-type model captures the predominant root fluxes. Accepting this, we estimated the total amounts of hydraulic lift (HL), hydraulic descent (HD), and soil water (SW) and groundwater (GW) contributions to stem flow at the whole tree level on a half-hourly basis. HL per tree was calculated multiplying the average sap flow of the sampled shallow connected roots (when negative) by the number of theoretical equivalent conductors (216). HD was calculated multiplying the sap flow of the sinker root (when negative, estimated by Eq. (2)) by the same number of theoretical equivalent conductors.

Soil water (SW) contribution to stem for each T-type connection was calculated when average deep connected root sap flow $>0$ (positive input to stem) and shallow connected root $>0(\mathrm{HL}=0)$, as:

If sinker root sap flow $<0$ (HD), SW contribution = shallow root connected flow + sinker root flow (HD, negative); Else, SW contribution $=$ shallow connected root flow .

Groundwater (GW) contribution to stem for each T-type connection was calculated when average deep connected root flow $>0$ (positive input to stem) and sinker root flow $>0(\mathrm{HD}=0)$, as:

If shallow root connected flow $<0 \quad(\mathrm{HL}), \mathrm{GW}$ contribution $=$ sinker root flow + shallow root flow (HL, negative); Else, GW contribution $=$ sinker flow .

SW and GW contributions of individual conductors were extrapolated to the whole tree multiplying by the theoretical number of equivalent conductors (216).

Calculations were done in $\mathrm{kg} \mathrm{h}^{-1}$ and integrated daily, monthly and yearly. Values were expressed in mm dividing by the crown projected area $\left(172.3 \mathrm{~m}^{2}\right)$. Results obtained were cross-validated and follow the requirements of the mass balance equation both for shallow connected, deep connected and sinker roots.

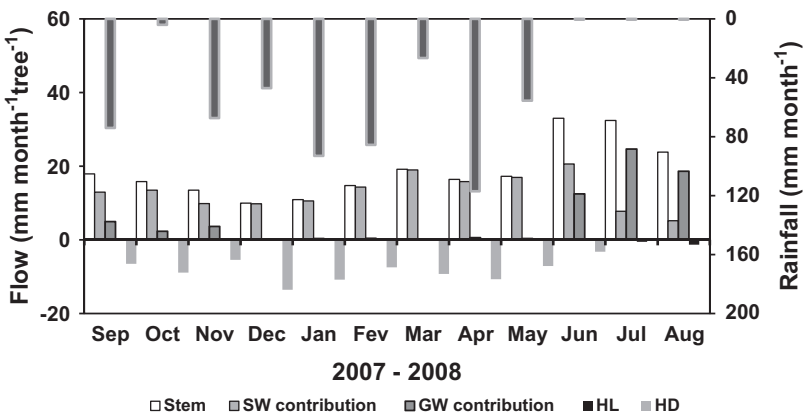

Fig. 9. Monthly values (September 2007-August 2008) of rainfall, stem sap flow, groundwater (GW) and soil water (SW) contributions to stem sap flow, hydraulic descent (HD) and hydraulic lift (HL) for the intensively studied $Q$. suber tree.

Fig. 9 shows the monthly values of the components of the water balance and of hydraulic redistribution (September 2007-August 2008 ) for the intensively studied tree. On an annual basis (September 2007-August 2008) rainfall was $571.3 \mathrm{~mm}$, stem flow $224.9 \mathrm{~mm}$, SW and GW contributions $69.5 \%$ and $30.5 \%$ of stem flow, respectively, and HL and HD $0.9 \%$ and $37.0 \%$ of stem flow, respectively. In December 2007 (when HD was highest), rainfall was $47.0 \mathrm{~mm}$, stem flow $9.9 \mathrm{~mm}$, SW and GW contributions 98.4\% and $1.6 \%$ of stem flow, respectively, and HL and HD 0 and $136.3 \%$ of stem flow, respectively. Highest and average daily HD were 0.9 and $0.44 \mathrm{~mm} \mathrm{day}^{-1}$ tree $^{-1}$, respectively. In August 2008 (when HL was highest), rainfall was $0.5 \mathrm{~mm}$, stem flow $23.8 \mathrm{~mm}$, SW and GW contributions $21.8 \%$ and $78.2 \%$ of stem flow, respectively, and HL and HD 5.6 and ca. $0 \%$ of stem flow, respectively. Highest and average daily HL were 0.09 and $0.04 \mathrm{~mm} \mathrm{day}^{-1}$ tree $^{-1}$, respectively.

\section{Discussion}

Under the strong seasonality of the Mediterranean climates, trees have to withstand a long dry season. Given the low waterholding capacity of the soil at our experimental site (sandy soil), we would expect Quercus suber trees to be subjected to water stress in summer. However, predawn leaf water potential of the intensively studied tree never decreased below $-0.5 \mathrm{MPa}$, similarly 
to what was observed in the neighboring ones. Likewise, tree transpiration, estimated by sap flow at stem breast height, reached a maximum during the dry summer, closely following the pattern of solar radiation $\left(R^{2}=0.73\right.$; Figs. 1 a and $\left.4 \mathrm{a}\right)$.

To sustain high transpiration rates in summer (given the low water content in the surface soil (Fig. 1)) trees need to be functionally connected to the groundwater reservoir (Canadell et al., 1996). The prevailing direct groundwater uptake by deep roots during the summer was confirmed by the $\delta^{18} \mathrm{O}$ signature of twig xylem, surface soil (averaged from 0.3 to $0.7 \mathrm{~m}$ depth) and groundwater (see Table 2). The role of groundwater supply in the maintenance of the transpiration of Mediterranean oaks during drought has already been reported elsewhere, though through different approaches (David et al., 2007; Lubczynski and Gurwin, 2005; Miller et al., 2010).

The maintenance of contact between roots and groundwater table was ensured at our site by the dimorphic root system (Fig. 2). A dense network of superficial roots, extending at least into the crown limits, mainly colonized the first $60 \mathrm{~cm}$ of soil. These roots are connected to sinkers, and some of them turn down vertically near the crown limits. The deepest roots extended at least below the lowest water table level observed during the experimental period (4.5 m deep). Below $3 \mathrm{~m}$ depth, tangles of hair-like deep roots were submerged during long periods of time, as evidenced by the water table fluctuations (Figs. 2 and 1c), apparently surviving periodic waterlogging. This could be ascribed to the presence of large areas of the cortex occupied by parenchyma aerenchyma (Fig. 2), a porous tissue that acts as a low resistance internal pathway for oxygen transport between roots and the aerial environment. Its formation seems to be triggered by periods of oxygen deficiency that promote a limited tolerance to anaerobic conditions (Colmer, 2003; Drew et al., 2000). Root mean vessel diameter showed a topdown decrease. Vessel area per unit of sampled area was higher in sinkers and deep fine root filaments (Fig. 3). The decreasing trend in vessel diameter with root depth observed in $Q$. suber is different from that reported by McElrone et al. (2004) for Juniperus ashei, Bumelia lanuginosa, Quercus fusiformis and Quercus sinuate, where higher vessel diameters were found in deep roots. The high proportion of vessel area in deep root filaments and sinker roots suggests that these organs are mainly oriented towards the transport of water. On the other hand, the taproot and the superficial lateral root (with a much smaller proportion of vessel area) seem to provide, in addition to water transport, an important structural support function.

The occurrence of hydraulic redistribution was detected by measuring sap flow (heat field deformation method) in five superficial roots (Figs. $4 \mathrm{~b}-\mathrm{f}$ ). In roots connected to deep soil layers or groundwater (deep connected roots, roots 1 and 4), hydraulic descent (negative flows) occurred at night during the wet seasons (Fig. $4 \mathrm{~b}$ and c). In roots 2, 3 and 5 (shallow connected roots), hydraulic lift (nighttime negative flows) was detected when superficial soil dried out (Fig. 1), in the dry periods of spring 2007 and summers of 2007 and 2008 (Fig. 4d-f). The occurrence of hydraulic redistribution has been documented in Q. suber (Kurz-Besson et al., 2006; Nadezhdina et al., 2008) and in different biomes, being a process more widespread than previously thought (Nadezhdina et al., 2010; Oliveira et al., 2005; Prieto et al., 2012).

Similarly to tree transpiration (stem sap flow), the sap flow in deep connected roots (roots 1 and 4 ) followed the radiation pattern, but water uptake through the shallow connected roots (roots 2, 3 and 5) strongly declined during the dry summers (Fig. 4). During the wet season, the contribution of individual shallow and deep connected roots was similar, but during the summer supply through the deep connected roots prevailed (Fig. 5).

Based on the two functional root types identified both in this work and by Nadezhdina et al. (2008), a conceptual model (Model
2, T-type) was tested considering that each superficial root might work as deep connected or shallow connected, depending on sensor position relative to the sinker root linked to it: part of the root works as deep connected (between the stem and the sinker) and part as shallow connected (between the sinker and superficial soil) (see Fig. 6). Number of theoretical equivalent conductors of deep and shallow connected roots was considered equal and estimated as 216 (see Section 3.7). As in all modeling attempts, this T-type model is a simplification of reality. For the T-type model the number of equivalent conductors estimated for deep connected roots (230) was slightly higher than for shallow connected roots (202) (see Section 3.7), though according to the model they should be equal (Fig. 6). Difference might reflect the existence of a small number of equivalent roots behaving as sinkers not connected to shallow roots. This may be the case of the taproot. However, and since the aforementioned difference is small, the T-type model seems to capture the predominant behavior of the overall root system.

Based on this model we: (1) estimated stem sap flow from root sap flow with a high accuracy both at tree and plot level (average of four trees) (see Section 3.7 and Fig. 7); (2) developed a conceptual framework for the dynamics of water fluxes in roots (Fig. 8), which is consistent with that measured in sampled roots (Figs. 4 and 5); (3) calculated the soil water (SW) and groundwater (GW) contributions to tree stem flow (see Section 3.8, Fig. 9); (4) calculated the amount of HL and HD per tree (see Section 3.8, Fig. 9). According to our results, the main source of water supply to trees is soil water. This predominant water uptake from soil occurred in autumn, winter and spring, when soil was wet and its water potential was higher than that at groundwater. Water uptake from groundwater was only relevant during the dry summer, becoming predominant during the two driest months (July and August, Fig. 9), when the upward pressure gradient (between dry soil and groundwater) exceeded the downward gravitational gradient. Soil water contribution to stem sap flow amounted to 69.5\%, 98.4\% and $21.8 \%$ on an annual, wet month (December) and dry month (August) basis, respectively. For the same periods groundwater contribution to stem flow amounted to $30.5 \%, 1.6 \%$ and $78.2 \%$, respectively. Hydraulic lift represented only $0.9 \%$ of annual stem flow and 5.6\% of stem flow in August. Maximum and mean daily HL in August were 0.09 and $0.04 \mathrm{~mm} \mathrm{day}^{-1}$ tree $^{-1}$, respectively. Hydraulic descent was much higher: $37 \%$ of stem flow on an annual basis and $136.3 \%$ of stem flow in December. Maximum and mean daily HD in December were 0.9 and $0.44 \mathrm{~mm}_{\text {day }}{ }^{-1}$ tree $^{-1}$, respectively.

The water balance components and the amounts of HR obtained for the intensively studied $Q$. suber tree should be also valid for all plot trees, since they were calculated according to Model 2 which simulates the average stem sap flow of four trees with a high efficiency.

Our estimates of hydraulic lift are in the lower range of those reported in a recent review by Neumann and Cardon (2012) (0.04-1.3 mm day ${ }^{-1}$ in experimental studies) and lower than those estimated for old growth Pinus ponderosa and Pseudotsuga menziesii stands (0.094-0.111 $\mathrm{mm} \mathrm{day}^{-1}$ ) (Warren et al., 2007). The values of hydraulic descent at our site are within the range reported by Neumann and Cardon (2012) (0.2-1.7 $\mathrm{mm} \mathrm{day}^{-1}$ in experimental studies). Previous estimates of both HL and HD were mainly based on soil moisture or soil water potential measurements. To the best of our knowledge, only one study estimated HL and HD based on root sap flow (Scott et al., 2008). Our results confirm the general tendency reported by Burgess et al. (2001) and Neumann and Cardon (2012) of HD being higher than HL. In our case annual HD $(83.2 \mathrm{~mm})$ exceeded annual tree groundwater use $(68.7 \mathrm{~mm})$. Hence, we could think that the tree was contributing to a net recharge of groundwater. Within this line of reasoning, some authors 
argue that HD may contribute to postpone the onset of drought extending the growth period (Scott et al., 2008). However, we think that this groundwater recharge would also occur in the absence of the tree, though at a slower rate, through soil water percolation. Nevertheless, the quick drainage of soil water through HD may be ecologically relevant, since it may prevent waterlogging and promote aeration in surface soil, contributing to the maintenance of optimal conditions for superficial roots.

At our site, hydraulic lift does not seem to have an immediate hydrological relevance (very small contribution to transpiration) as observed in other studies (Domec et al., 2012; Markewitz et al., 2010; Newman and Cardon, 2012). However, it can be ecologically important for up taking nutrients from the upper soil (Neumann and Cardon, 2012; Ryel et al., 2010). The trees at our site only perform HL when groundwater supply is dominant (Fig. 9). Since the groundwater is usually poor in nutrients, HL may compensate for that through the release and reabsorption of water into and from top soil, which is the main pool for nutrient supply (Ryel et al., 2010). HL can also be important for maintaining fine roots, mycorrhizal hyphae, soil-water contact and preventing embolism (Neumann and Cardon, 2012; Scott et al., 2008).

As hypothesized, we were able to successfully model the bulk of the functional traits of the root system of $Q$. suber trees and explain how they cope with seasonal drought. The trees maximize the exploitation of the environmental resources by using the topsoil water most of the year, and groundwater together with hydraulic lift (nutrient supply) in the dry summer.

Our findings have important implications for the management of $Q$. suber stands under shallow water table conditions. Any sudden groundwater table decline, due to water abstraction may result in additional tree water stress, crown dieback or even tree death (Cooper et al., 2003). The response of $Q$. suber trees to the expected increase in the length and severity of seasonal summer drought due to climate change will probably result in a decrease in soil water uptake and hydraulic descent and an increase in groundwater uptake and hydraulic lift. In the long-term the progressive lowering of water table level may threaten the sustainability of these ecosystems. Furthermore, Q. suber woodlands are usually exploited as agroforestry systems, with trees associated to crops or pasture. Ploughing is a common practice under such conditions. By damaging or destroying superficial roots, it may disconnect trees from the nutrient and water pools (both soil and groundwater) also contributing to tree decline and mortality. Therefore, minimum tillage techniques should be recommended in Mediterranean oak woodlands.

\section{Acknowledgements}

This work was supported by the Portuguese Foundation for Science and Technology (FCT) (Projects POCI-PTDC/AGR/59152/2004) and Czech national projects (MSM 6215648902 and IGA LDF 12/ 2010). Clara A. Pinto was funded by a doctoral grant from FCT (SFRH/BD/46479/2008). We thank Rui Alves and Vitor Barros (Companhia das Lezirias) for providing site facilities, Nuno Cortez and Joaquim Mendes (Inst. Sup. Agronomia) for field assistance. We thank the anonymous reviewers for the helpful and constructive comments on the manuscript.

\section{References}

Allen, C.D., Macalady, A.K., Chenchouni, H., Bachelet, D., McDowell, N., Vennetier, M., Kitzberger, T., Rigling, A., Breshears, D.D., Hogg, E.H., Gonzalez, P., Fensham, R., Zhang, Z., Castro, J., Demidova, N., Lim, J.H., Allard, G., Running, S.W., Semerci, A., Cobb, N., 2010. A global overview of drought and heat-induced tree mortality reveals emerging climate change risks for forests. For. Ecol. Manage. 259, 660684.
Baldocchi, D.D., Xu, L., 2007. What limits evaporation from Mediterranean oak woodlands - the supply of moisture in the soil, physiological control by plants or the demand by the atmosphere? Adv. Water Resour. 30, 2113-2122.

Burgess, S.S.O., Adams, M.A., Turner, N.C., White, B.A., Ong, C.K., 2001. Tree roots: conduits for deep recharge of soil water. Oecologia 126, 158-165.

Canadell, J., Jackson, R.B., Ehleringer, J.R., Mooney, H.A., Sala, O.E., Schulze, E.D., 1996. Maximum rooting depth of vegetation types at the global scale. Oecologia $108,583-595$.

Cermak, J., Huzulak, J., Penka, M., 1980. Water potential and sap flow rate in adult trees with moist and dry soil as used for assessment of the root system depth. Biol. Plant. 22, 34-41.

Colmer, T.D., 2003. Long-distance transport of gases in plants: a perspective on internal aeration and radial oxygen loss from roots. Plant, Cell Environ. 26, 1736.

Cooper, D.J., D’Amico, D.R., Scott, M.L., 2003. Physiological and morphological response patterns of Populus deltoides to alluvial groundwater pumping. Environ. Manage. 31, 215-226.

David, T.S., David, J.S., Pinto, C.A., Cermak, J., Nadezhdin, V., Nadezhdina, N., 2012. Hydraulic connectivity from roots to branches depicted through sap flow: analysis on a Quercus suber tree. Funct. Plant Biol. 39, 103-115.

David, T.S., Ferreira, M.I., Cohen, S., Pereira, J.S., David, J.S., 2004. Constraints on transpiration from an evergreen oak tree in southern Portugal. Agr. For. Meteorol. 122, 193-205.

David, T.S., Henriques, M.O., Besson, C.K., Nunes, J., Valente, F., Vaz, M., Pereira, J.S., Siegwolf, R., Chaves, M.M., Gazarini, L.C., David, J.S., 2007. Water use strategies in two co-occurring Mediterranean evergreen oaks: surviving the summer drought. Tree Physiol. 27, 793-803.

Dawson, T.E., 1996. Determining water use by trees and forests from isotopic, energy balance and transpiration analyses: the roles of tree size and hydraulic lift. Tree Physiol. 16, 263-272.

Dawson, T.E., Ehleringer, J.R., 1993. Isotopic enrichment of water in the "woody" tissues of plants: implications for water source, water uptake, and other studies which use the stable isotopic composition of cellulose. Geochim. Cosmochim. Acta 57, 3487-3492.

Domec, J.-C., Ogée, J., Noormets, A., Jouangy, J., Gavazzi, M., Treasure, E., Sun, G., McNulty, S.G., King, J.S., 2012. Interactive effects of nocturnal transpiration and climate change on the root hydraulic redistribution and carbon and water budgets of southern United States pine plantations. Tree Physiol. 32, 707-723.

Drew, M.C., He, C.-J., Morgan, P.W., 2000. Programmed cell death and aerenchyma formation in roots. Trends Plant Sci. 5 (3), 123-127.

Granier, A., 1985. Une nouvelle méthode pour la mesure du flux de sève brute dans le tronc des arbres. Ann. For. Sci. 42, 193-200.

IPCC, 2007. Climate change 2007: impacts, adaptation and vulnerability, In: Parry, M.L., Canziani, O.F., Palutikof, J.P., van der Linden, P.J., Hanson, C.E. (Eds.) Contribution of Working Group II to the Fourth Assessment Report of the Intergovernmental Panel on Climate Change. Cambridge University Press, Cambridge, UK.

Jackson, R.B., Moore, L.A., Hoffmann, W.A., Pockman, W.T., Linder, C.R., 1999. Ecosystem rooting depth determined with caves and DNA. PNAS 96, 1138711392.

Kurz-Besson, C., Otieno, D., Lobo-do-Vale, R., Siegwolf, R., Schmidt, M., Herd, A., Nogueira, C., David, T.S., David, J.S., Tenhunen, J., Pereira, J.S., Chaves, M., 2006. Hydraulic lift in cork oak trees in a savannah-type Mediterranean ecosystem and its contribution to the local water balance. Plant Soil 282, 361-378.

Lubczynski, M.W., Gurwin, J., 2005. Integration of various data sources for transient groundwater modeling with spatio-temporally variable fluxes - Sardon study case. Spain J. Hydrol. 306, 71-96.

Markewitz, D., Devine, S., Davidson, E.R., Brando, P., Nepstad, D.C., 2010. Soil moisture depletion under simulated drought in the Amazon: impacts on deep root uptake. New Phytol. 187, 592-607.

Martínez-Vilalta, J., Prat, E., Oliveras, Imma., Piñol, J., 2002. Xylem hydraulic properties of roots and stems of nine Mediterranean woody species. Oecologia 133, 19-29.

McElrone, A.J., Pockman, W.T., Martínez-Vilalta, J., Jackson, R.B., 2004. Variation in xylem structure and function in stems and roots of trees to $20 \mathrm{~m}$ depth. New Phytol. 163, 507-517.

Miller, G.R., Chen, X., Rubin, Y., Ma, S., Baldocchi, D.D., 2010. Groundwater uptake by woody vegetation in a semiarid oak savanna. Water Resour. Res., vol. 46, W10503 (14 pp.).

Moreno, G., Obrador, J.J., Cubera, E., Dupraz, C., 2005. Fine root distribution in Dehesas of Central-Western Spain. Plant Soil 277, 153-162.

Nadezhdina, N., David, T.S., David, J.S., Ferreira, M.I., Dohnal, M., Tesar, M., Gartner, K., Leitgeb, E., Nadezhdin, V., Cermak, J., Jimenez, M.S., Morales, D., 2010. Trees never rest: the multiple facets of hydraulic redistribution. Ecohydrol 3, 431444.

Nadezhdina, N., Ferreira, M.I., Silva, R., Pacheco, C.A., 2008. Seasonal variation of water uptake of a Quercus suber tree in Central Portugal. Plant Soil 305, 105119.

Neumann, R.B., Cardon, Z.C., 2012. The magnitude of hydraulic redistribution by plant roots: a review and synthesis of empirical and modeling studies. New Phytol. 194, 337-352.

Oliveira, R.S., Dawson, T.E., Burgess, S.S.O., Nepstad, D.C., 2005. Hydraulic redistribution in three Amazonian trees. Oecologia 145, 354-363.

Peñuelas, J., Lloret, F., Montoya, R., 2001. Severe drought effects on Mediterranean woody flora in Spain. For. Sci. 47 (2), 214-218. 
Pinto, C.A., David, J.S., Cochard, H., Caldeira, M.C., Henriques, M.O., Quilhó, T., Paço, T.A., Pereira, J.S., David, T.S., 2012. Drought-induced embolism in current-year shoots of two Mediterranean evergreen oaks. For. Ecol. Manage. 285, 1-10.

Prieto, I., Armas, C., Pugnaire, F.I., 2012. Water release through plant roots: new insights into its consequences at the plant and ecosystem level. New Phytol. $193,830-841$

Ryel, R.J., Leffler, A.J., Ivans, C., Peek, M.S., Caldwell, M.M., 2010. Functional differences in water-use patterns of contrasting life forms in the Great Basin steppelands. Vadose Zone J. 9, 548-560.

Schenk, H.J., Jackson, R.B., 2002. Rooting depths, lateral root spreads and belowground/above-ground allometries of 134 plants in water-limited ecosystems. J. Ecol. 90, 480-494.
Scholander, P.F., Hammel, H.T., Bradstreet, E.D., Hemmingsen, E.A., 1965. Sap pressure in vascular plants. Science $148,339-346$.

Scott, R.L., Cable. W.L., Hultine, K.R., 2008. The ecohydrologic significance of hydraulic redistribution in a semiarid savanna. Water Resour. Res. 240, W02440 (12 pp.).

van Mantgem, P.J., Stephenson, N.L., Byrne, J.C., Daniels, L.D., Franklin, J.F., Fulé, P.Z., Harmon, M.E., Larson, A.J., Smith, J.M., Taylor, A.H., Veblen, T.T., 2009 Widespread increase of tree mortality rates in the Western United States. Science 323, 521-524.

Warren, J.F., Meinzer, F.C., Brooks, J.R., Domec, J.C., Coulombe, R., 2007. Hydraulic redistribution of soil water in two old-growth coniferous forests: quantifying patterns and controls. New Phytol. 173, 753-765. 